\title{
Pyoderma Gangrenosum: A Review Article
}

\author{
Pioderma Gangrenoso: Um Artigo de Revisão
}

Clóvis Luíz Konopka, ${ }^{1}$ Geórgia Andrade Padulla, ${ }^{2}$ Michele Purper Ortiz, ${ }^{3}$

Anderson Kahl Beck, ${ }^{4}$ Mariana Rechia Bittencourt, ${ }^{5}$ Diogo Chagas Dalcin ${ }^{6}$

\begin{abstract}
Pyoderma gangrenosum (PG) is a chronic dermatosis with peculiar characteristics and uncertain etiology, often difficult to diagnose. Painful skin ulcers form rapidly and progressively, most commonly in the lower limbs. Ulcerations may occur spontaneously or after various types of trauma. The time between the onset of lesions and the correct diagnosis is often long. There is no standard treatment or simple algorithm for the choice of therapy. In this study, we conducted a comprehensive review of current literature on the pathophysiology, diagnosis, and treatment of this disease through the systematic analysis of references in four databases, namely PubMed, Scielo, Medline and Lilacs.
\end{abstract}

Keywords: pyoderma gangrenosum; skin ulcer; differential diagnosis.

\section{Resumo}

O pioderma gangrenoso (PG) é uma dermatose crônica com características peculiares e de etiologia desconhecida, muitas vezes de difícil diagnóstico. Manifesta-se através de lesões cutâneas ulceradas e dolorosas com evolução rápida e progressiva, mais comumente em membros inferiores. As ulcerações podem surgir espontaneamente ou depois de variados tipos de trauma. O período entre o início das lesões e o diagnóstico correto costuma ser prolongado. Não existe nenhum tratamento padronizado ou algoritmo simples para a escolha da terapia. Neste artigo, os autores fazem uma ampla revisão da literatura atual acerca da fisiopatologia, do diagnóstico e do tratamento desta patologia através de análise sistemática das referências bibliográficas atuais nas bases de dados PubMed, Scielo, Medline e Lilacs.

Palavras-chave: pioderma gangrenoso; úlcera cutânea; diagnóstico diferencial.

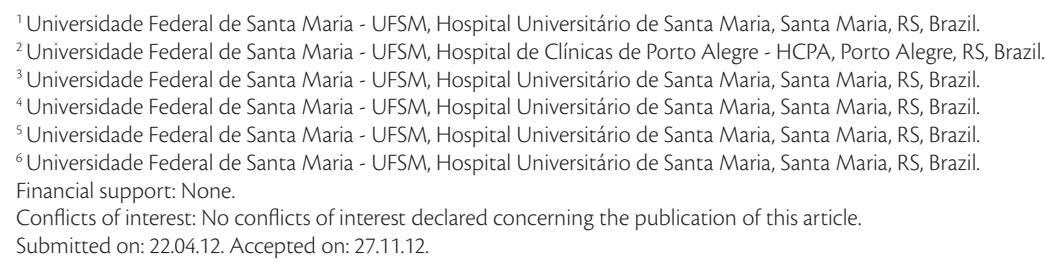




\section{INTRODUCTION}

Pyoderma gangrenosum (PG) is a rare, chronic and often recurrent neutrophilic dermatosis. Its etiology is uncertain, and it is often associated with inflammatory bowel diseases (ulcerative colitis and Crohn's disease), malignancies, arthritis and blood dyscrasias. It may even mimic, in certain cases, surgical wound infections. ${ }^{1}$

This disease, first described in 1916 by Brocq, was later better characterized by Brusting in $1930,{ }^{2}$ who named it PG because it was believed to be a streptococcal infection causing skin gangrene. Currently, its pathogenesis remains mostly uncertain, but it has been defined that PG is not directly caused by bacteria and is not, therefore, an infectious pathology. ${ }^{3}$

Its incidence is estimated at 3 to 10 cases per million people per year, ${ }^{4,5}$ and several studies in the literature report on single cases or small patient series. In the United States, the Mayo clinic diagnosed only 180 cases of PG in 53 years. ${ }^{4,6}$

PG affects individuals of any age, but is more common in young adults 25 to 54 years old, and affects women more often than men. ${ }^{2}$ It rarely affects children (less than $4 \%$ of the cases), in which case it is usually associated with other systemic diseases. ${ }^{7}$ Reports published in scientific journals refer to its development in immunodepressed patients due to immunosuppressive therapy or chemotherapy, as well as in cases of HIV infection. ${ }^{5,6}$

The clinical presentation of $\mathrm{PG}$ is variable, but essentially characterized by multiple or single painful ulcerative skin lesions that progress rapidly and have a mottled, erythematous appearance. ${ }^{8}$ Lower limbs are its most common site., ${ }^{5,9}$

This study conducted a broad review of the current literature about the clinical and pathological aspects of PG, its differential diagnosis and its treatment by systematic analysis of references in the PubMed, Scielo, Medline and Lilacs databases from 1992 to 2012 using the following keywords (in English and Portuguese): pyoderma gangrenosum, pioderma gangrenoso, neutrophilic dermatosis, skin ulcer and úlcera cutânea. In addition to the electronic search, other articles, relevant for the production of our manuscript, were specifically selected using the Periódicos Capes tool.

\section{PATHOGENESIS}

The initial lesion usually has the appearance of a nodule or pustule that, as it breaks, progressively forms an ulcer with a necrotic center and irregular borders. Neutrophils are prominently found in the lesions, and abnormalities in their functions, such as defects in their chemotaxis or hyperresponsiveness, have been reported a few times. ${ }^{2}$ Autoantibodies to skin antigens have also been described, but there has been no confirmation that they may be associated with the causes of the skin lesions. ${ }^{3}$ Evidence of disorders in immune cells is convincing, ${ }^{10}$ but insufficient to fully explain PG pathogenesis. Lazarus et al. ${ }^{11}$ found no response to intradermal injection of purified protein derived from tuberculin, streptokinase-streptodornase and mumps antigens. Greenberg et al. ${ }^{12}$ reported that the inhibition of several cell immune responses was mediated by a non-dialyzable and thermostable serum factor, specifically in one patient under study. This factor inhibited allogeneic and autologous lymphocytic proliferation and the production of leukocyte inhibitory factor. ${ }^{3}$ In an experiment, a circulatory dermonecrotic factor found in the serum of patients with PG induced necrosis in the skin of pigs, but its effect in humans has not been determined.

A possible key to explaining PG etiology may be its frequent association with systemic diseases, which have well-known autoimmune mechanisms. According to some authors, pathergy, which explains the development of new lesions after local trauma and is suggestive of an altered, exaggerated and incontrollable inflammatory response to unspecific stimuli, might also be found in PG lesions.

Therefore, despite all scientific advances in understanding $\mathrm{PG}$, its pathogenesis remains uncertain. Evidence points to immune disorders as the factors responsible for its etiology, but such changes seem to be detectable only in isolated patients. ${ }^{13}$ Nevertheless, several authors classify PG as a disease of immune origin.

\section{CLINICAL PRESENTATION}

PG usually begins as a painful deep nodule or a hemorrhagic superficial pustule, often after minor skin trauma. ${ }^{14}$ The nodule or pustule is characteristically followed by the appearance of a dark red or purplish inflammatory, painful ulcerative lesion with irregular borders and a granular necrotic base, usually mottled with small abscesses. A hemorrhagic and purulent exudate is produced inside the ulcerative lesions. The peripheral growth of the lesions gives them a serpiginous configuration resulting from edge undermining and the appearance of new hemorrhagic pustules. Superficial ulcers may be confined to the dermis, but usually extend into the fat-laden panniculus and the underlying fascia. Lesions are often single, but coalescent lesions may 
also be seen. They usually appear simultaneously or consecutively in different parts of the body, ${ }^{2}$ with a predilection for the lower limbs, buttocks and abdomen. ${ }^{1,15}$ Mucous membranes are usually spared, but aphthae may appear in the oral mucosa, often affecting the oral cavity, larynx and pharynx massively.

Several times the lesions appear after minor trauma, such as injections, insect bites, biopsies, or surgical incisions, ${ }^{1,16,17}$ which suggests the occurrence of the phenomenon known as pathergy. ${ }^{18}$ Systemic symptoms, such as fever, arthralgia and myalgia, may be associated..$^{19}$ Extracutaneous involvement of bones and lungs has already been described, with the presence of neutrophilic infiltrates. ${ }^{17,20}$

PG onset may follow two distinct clinical progression patterns:

- Sudden onset with rapid spread of lesions, clinically characterized by pain, systemic toxicity, fever, hemorrhagic pustules, suppuration and borders with an inflammatory halo.

- Slow and indolent onset, which massive granulation inside the ulcer, crust and hyperkeratosis in the edges, involving large areas and characterized by spontaneous retrogression in certain areas and progression in others. ${ }^{2}$

PG has four different clinical and histopathological variants:

1. Vegetative $-12.5 \%{ }^{21}$ : Limited and not aggressive, has superficial verrucose lesions and a non-purulent base (Figure 1), which differentiates it from the ulcerative variant. It is also called superficial granulomatous pyoderma and usually affects the trunk, head or neck. Many patients have no associated systemic diseases and respond to appropriate therapy rapidly. The differential diagnosis should include infections by mycobacteria, sporotrichosis and skin malignancies. ${ }^{22}$

2. Bullous $-6.25 \%^{21}$ : Associated with leukemia, its onset is sudden; it is more superficial and characterized by purple papules and bluish, bullous and hemorrhagic lesions (Figure 2). Its differential diagnosis should include acute febrile neutrophilic dermatosis (Sweet syndrome), cellulitis, bullous dermatosis and spider bites. ${ }^{22,23}$

3. Ulcerative $-81.52 \%{ }^{21}$ : Begins with a small pustule surrounded by an inflammatory halo (Figure 3), is painful and progresses rapidly. Lesion resolution results in atrophic cribriform scarring. ${ }^{24}$ Malignant pyoderma, an aggressive and potentially lethal variant of ulcerative PG, usually affects the head and neck and may be associated with systemic vasculites. The differential diagnosis should include systemic vasculites (Wegener granulomatosis, cryoglobulinemia, polyarteritis nodosa and antiphospholipid antibody syndrome), infections (sporotrichosis, ame- biasis, syphilitic ulcer and ecthyma gangrenosum), ${ }^{1}$ malignancies, ischemic ulcers and insect bites. ${ }^{22}$

4. Pustular-rare: It is associated with fever and arthralgia, frequently associated with inflammatory bowel diseases (IBD). ${ }^{6,25}$ Pustules may either progress or not into ulcerative lesions (Figure 4) and usually affect the extensor side of extremities. After IBD is controlled, it may retrogress without scarring, but lesions may coexist with the ulcerative variant. ${ }^{22}$ Periostomal PG in colostomies or ileostomies is a rarer variant reported almost exclusively in patients with IBD. ${ }^{26}$ The differential diagnosis should include pustular vasculites, folliculitis and pustular eruption due to drugs and infections. ${ }^{22}$

\section{LABORATORY FINDINGS}

There are no specific laboratory findings. Tests show leukocytosis and invariably elevated erythrocyte sedimentation rate and protein C-reactive levels. ${ }^{4}$ There may be anemia and low serum iron

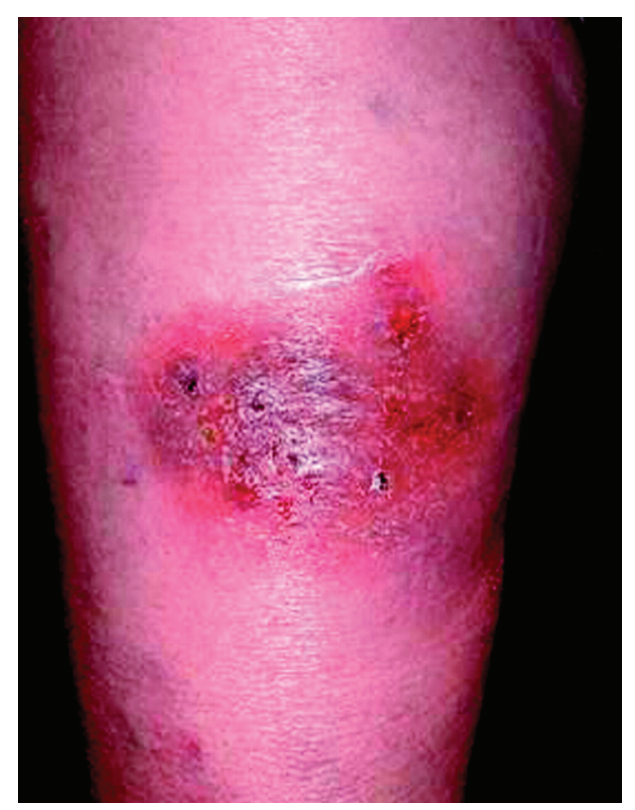

Figure 1. Vegetative PG.

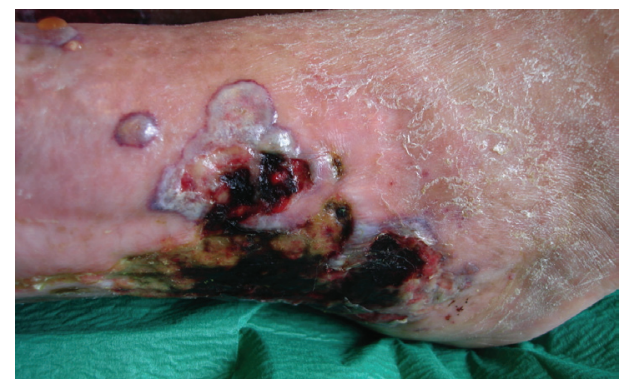

Figure 2. Bullous PG. 
levels, as well as hyper- and hypoglobulinemia. Specific autoantibodies are not usually found, and circulating immunocomplexes are not detected.

\section{HISTOPATHOLOGY}

Histopathological findings are not characteristics and may include edema, neutrophilic infiltrate, small and medium-caliber vessel thrombosis, necrosis and hemorrhage. Polymorphonuclear leukocyte infiltrate is usually extremely dense, which leads to the formation of microabscesses with liquefaction necrosis associated with the secondary thrombosis of venules. Neutrophils are PG markers. ${ }^{3}$

The occurrence of necrotizing vasculitis is controversial, and some authors have described only the presence of fibrinoid necrosis, whereas others found lymphocytic vasculites or describe it as indistinguishable from the lesions found in immunocomplex diseases. Nevertheless, the current correlation between $\mathrm{PG}$ and necrotizing vasculitis is important. $^{2}$

Histopathological findings also depend on the biopsy site (edge, center or necrotic area of the ulcer), the stage of progression and the disease variant (vegetative, bullous, ulcerative or pustular). ${ }^{6}$

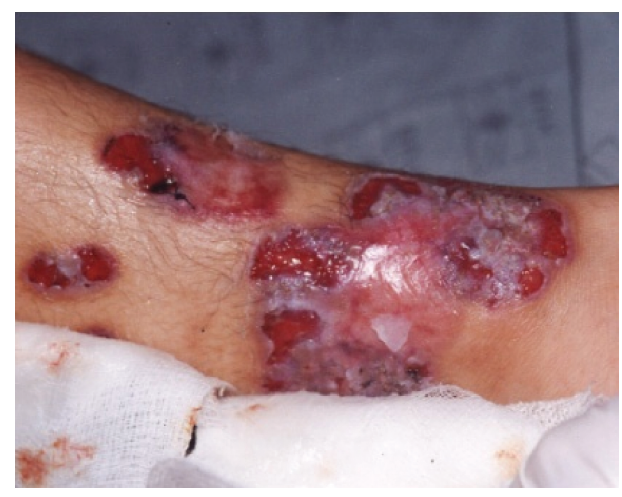

Figure 3. Ulcerative PG

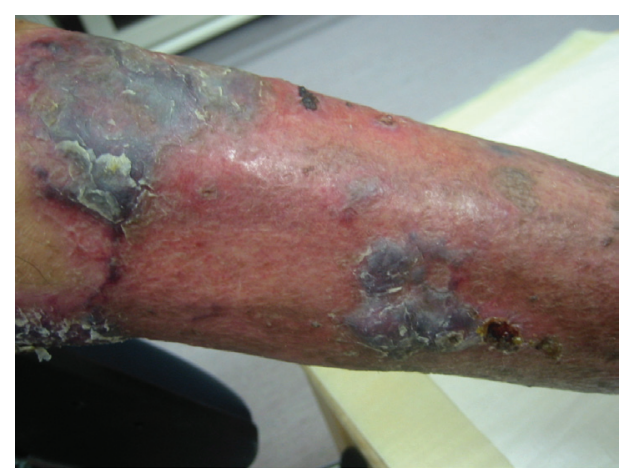

Figure 4. Pustular PG.

\section{ASSOCIATION WITH SYSTEMIC DISEASES}

In $50 \%$ to $70 \%$ of all cases, PG is associated with systemic diseases, such as inflammatory bowel diseases (idiopathic ulcerative colitis and Crohn's disease), rheumatoid arthritis, paraproteinemia, multiple myeloma, leukemia, chronic active hepatitis, Behçet's disease, malignancies, HIV infection and immunosuppression in transplant recipients. ${ }^{8,24,25,27-29}$ In the other cases, PG is a primary, isolated lesion limited to the skin and is, therefore, classified as idiopathic.

In the case of inflammatory bowel diseases, PG is found in about $5 \%$ of the cases of ulcerative colitis, and in only $0 \%$ to $1.2 \%$ of the cases of Crohn's disease. ${ }^{6,30}$ In most patients with colitis, bowel symptoms precede PG onset. However, in some cases PG skin lesions are seen first and may persist for a long time, whereas IBD symptoms may remain quiescent. Some reports also associate it with psoriasis and the development of lesions in the inguinal, axillary, perineal and penile regions. ${ }^{31}$

\section{DIAGNOSIS}

As mentioned above, there are no specific laboratory findings or pathognomic histological characteristics and, therefore, PG diagnosis depends exclusively on the observation of clinical characteristics and disease progression. However, some criteria may be suggestive of PG, such as the fact that ulcerative lesions are painful and progress rapidly from onset. Other criteria should also be taken into consideration, such as the presence of pathergy, the association with systemic diseases (secondary PG) and a rapid response to the administration of corticosteroids. Histopathological examination of biopsy material may show sterile neutrophilia and lymphocytic vasculites, ${ }^{18}$ which may exclude other etiologies of skin ulcers. ${ }^{26,32}$

Ferrándiz-Pulido and Briones ${ }^{24}$ recommend the following routine to establish the diagnosis of an ulcerative lesion:

1. Clinical history - rapid or slow progression, no response to antibiotics, associated diseases.

2. Physical exam - necrotic ulcer, purple erythematous edges, involvement of other organs.

3. Skin biopsy for Gram stains and culture - bacteria, fungi and mycobacteria.

4. Skin biopsy for histopathological examination (HE, PAS)*.

5. Laboratory blood tests - complete blood count, biochemical parameters, erythrocyte sedimentation rate, protein electrophoresis, clotting, anticardiolipin antibodies, antiphospholipid antibodies, ANCA* and cryoglobulins. 


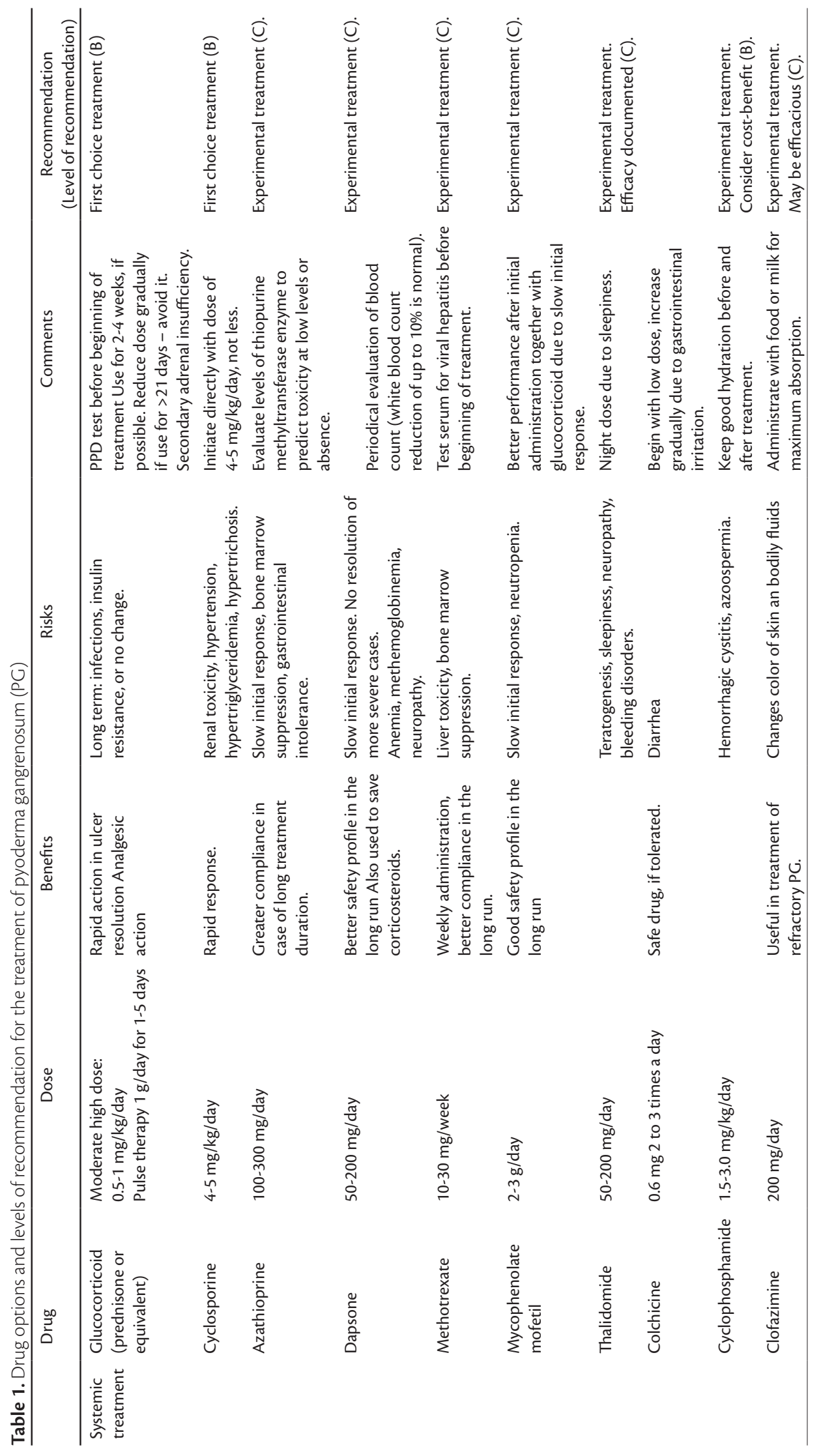




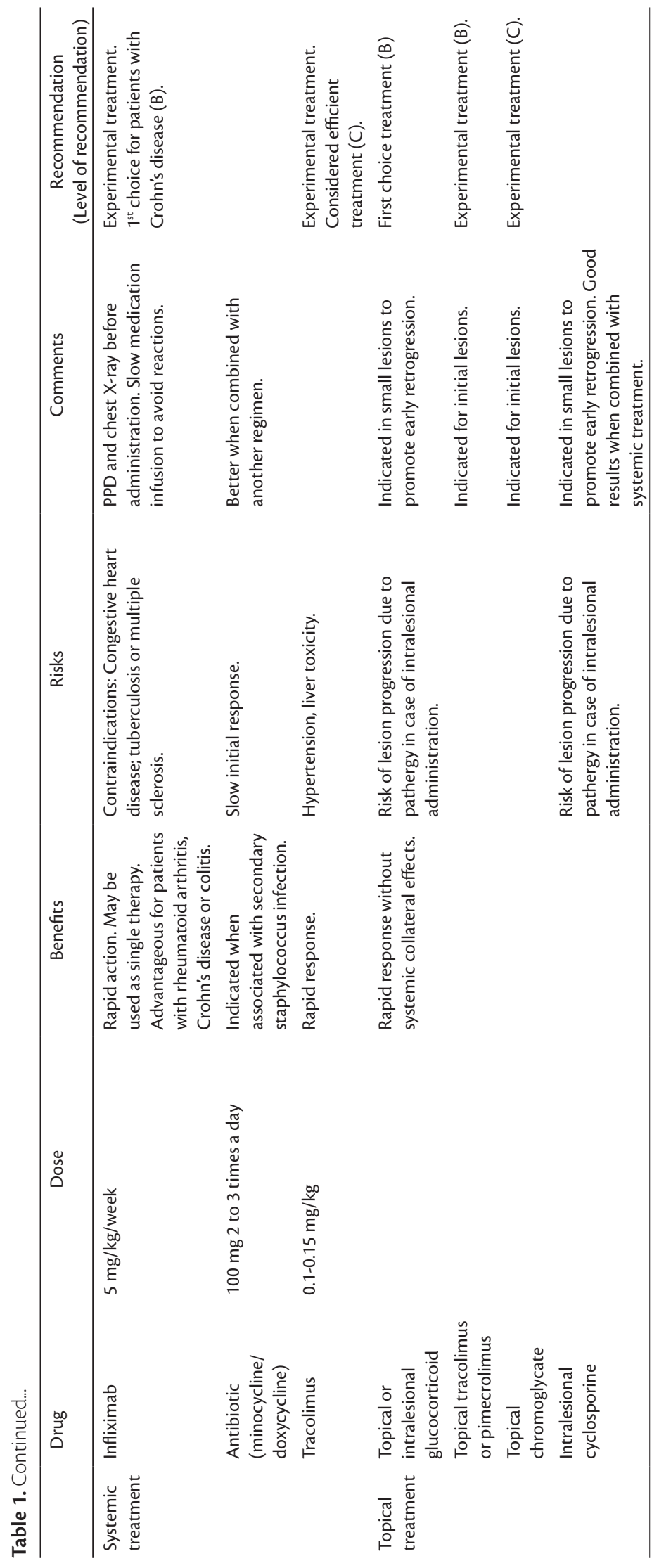


6. Chest X-ray

7. Abdominal ultrasound.

8. If digestive symptoms are present: upper digestive tract endoscopy and colonoscopy.

9. If complete blood count shows abnormalities: bone marrow aspirate and biopsy.

*ANCA: antineutrophil cytoplasmic antibodies; HE: hematoxylin-eosin; PAS: periodic acid Schiff protocol.

\section{TREATMENT}

The main objective of PG treatment is to limit tissue destruction, promote wound healing and obtain a good esthetic result. Surgical debridement and skin grafts should be avoided because of the potential risk of pathergy and the consequent lesion deterioration. ${ }^{4,33}$

Simple direct cleaning procedures and aseptic dressing are indicated. Moreover, the administration of medication should almost always be taken into consideration to promote healing of existing ulcers and prevent new lesions. In this sense, treatments available include the use of topical or intralesional corticosteroids, ${ }^{34} 6$-mercaptopurine or azathioprine, topical chromoglycate, dapsone, clofazimine and cyclosporine, as seen in Table 1. Hyperbaric oxygen therapy may be indicated for patients that do not tolerate or do not respond to high doses of systemic corticosteroids. ${ }^{35,36}$

Administration of systemic corticosteroids is the most effective treatment of PG., ${ }^{4,8}$ The use of corticosteroids may interrupt ulcerative progression and prevent the development of new lesions. High initial doses are necessary in most cases, usually about $100-200 \mathrm{mg} /$ day of prednisolone or $60-80 \mathrm{mg} /$ day of prednisone..$^{5,8,37}$

The use of sulfas may be beneficial, but response is not uniform. Daily doses range from 4 to $6 \mathrm{~g}$ and should be reduced progressively after some clinical improvement is observed to about 0.5 to 1 g/day. These drugs may be added to treatment in combination with corticosteroids in the initial phase of the disease. ${ }^{39}$ Alternatively, cyclosporine, at 6-10 $\mathrm{mg} / \mathrm{kg} /$ day, may produce significant improvement and lesion healing in about 1 to 3 months. Some authors reported on the use of clofazimine at daily doses of 200-300 mg; they found that lesion progression was interrupted in 1 to 2 months and full healing was achieved in up to 5 months. ${ }^{3}$ Oral thalidomide was efficient in a patient that did not respond to high doses of corticosteroids, and complete lesion cure was achieve after 10 weeks of administration. ${ }^{38}$ TNF-alpha inhibitors, such as infliximab, have been used with good results, ${ }^{25,39}$ especially for patients whose other comorbidities also improve with the use of this drug. In the cases of PG secondary to Crohn's disease, this drug is the treatment of choice. , $^{4,37}$

Surgery may play a role in the treatment of PG secondary to IBD in unstable patients that do not respond to medication. ${ }^{6}$ Colectomy may be considered in cases of extensive colitis, but the ulcerative lesions may persist after surgery. ${ }^{26,40}$

\section{CONCLUSIONS}

PG has an unpredictable and highly variable course from its onset and during its progression. ${ }^{41}$ Some patients develop lesions of sudden onset associated with progressive increase, followed by pain and fever. Others have chronic lesions, with ulcerations that progress slowly. Regardless of the variant, most lesions are self-limiting and progress to spontaneous healing in a short time. ${ }^{6}$ Some patients have recurrent lesions periodically. Also, some do not respond to the medications commonly used, which then have to be empirically replaced while other drugs are added to ensure PG cure or retrogression. ${ }^{4,8,42}$ Prognosis is usually good, especially for patients that rapidly respond to the initial treatment regimen. ${ }^{43}$ Similarly, the lesions of patients with secondary PG usually retrogress after the treatment of the primary disease. ${ }^{4,43}$

\section{REFERENCES}

1. Ogon $M$, Wimmer $C$, Behensky H, Sepp NT. A surgical wound infection? Lancet. 2000;356:1652. http://dx.doi.org/10.1016/ S0140-6736(00)03161-5

2. Bennet $M L$, Jackson JM, Jorizzo JL, Fleischer Junior $A B$, White WL, Callen JP. A comparison of typical and atypical forms with an emphasis on time to remission. Case review of 86 patients from 2 institutions. Medicine. 2000;79:37-46. http://dx.doi. org/10.1097/00005792-200001000-00004

3. Fitzpatrick TB, Eisen AZ, Wolf K, Fredberg IM, Austen KFK. Dermatology in general medicine. McGraw-Hill; 1993. p.1173-79.

4. Ahronowitz I, Harp J, Shinkai K. Etiology and management of pyoderma gangrenosum: a comprehensive review. Am J Clin Dermatol. 2012;13(3):191-211. PMid:22356259. http://dx.doi. org/10.2165/11595240-000000000-00000

5. Bolognia JL, Jorizzo JL, Rapini RP. Pyoderma gangrenosum. Dermatology. 2003;1:415-418.

6. Alam M, Grossman ME, Schneiderman PI, Blume RS, Benvenisty Al. Surgical management of pyoderma gangrenosum: case report and review. Dermatol Surg. 2000; 26(11):1063-6. PMid:11096397. http://dx.doi.org/10.1046/j.1524-4725.2000.0260111063.x

7. Sarma N, Bandyopadhyay SK, Boler AK, Barman M. Progressive and Extensive Ulcerations in a Girl Since 4 Months of Age: The Difficulty in Diagnosis of Pyoderma Gangrenosum. Indian J Dermatol. 2012;57(1):48-49. PMid:22470210 PMCid:3312658. http://dx.doi.org/10.4103/0019-5154.92678 
8. Reichrath J, Bens G, Bonowitz A, Tilgen W. Treatment recommendations for pyoderma gangrenosum: an evidencebased review of the literature based on more than 350 patients. J Am Acad Dermatol. 2005;53:273-83. PMid:16021123. http:// dx.doi.org/10.1016/j.jaad.2004.10.006

9. Barbato MT, Bakos L, Masiero NCMS, Bolson. Perfil clinicopatológico dos pacientes com pioderma gangrenoso do Hospital de Clínicas de Porto Alegre (RS) - Brasil (2000-2006). An Bras Dermatol. 2008;83(5):431-6. http://dx.doi.org/10.1590/ S0365-05962008000500006

10. Coors EA, Von Den Driesh P. Pyoderma gangrenosum in a patient with autoimmune haemolytic anaemia and complement deficiency. Br J Dermatol. 2000;143(1):154-6. http://dx.doi. org/10.1046/j.1365-2133.2000.03606.x

11. LazarusGS, Goldsmith LA, Rocklin RE, Pinals RS, DeBuisseretJP, David JR. Pyoderma gangrenosum, altered delayed hypersensitivity and polyarthritis. Arch Dermatol. 1972;105(1):46-51. PMid:5009622. http://dx.doi.org/10.1001/archderm.1972.01620040018003

12. Greenberg SJ, Jegasothy BV, Johnson RB,Lazarus GS. Pyoderma GangrenosumOccurrence With Altered Cellular Immunity and a Circulating Serum Factor. Arch Dermatol. 1982;118(7):498502. PMid:7092276. http://dx.doi.org/10.1001/ archderm.1982.01650190052019

13. Khandpur S, Mehta S, Reddy BS. Pyoderma gangrenosum in two siblings: a familial predisposition. Pediatr Dermatol. 2001;18:308-12. PMid:11576404. http://dx.doi. org/10.1046/j.1525-1470.2001.01936.x

14. Hadi A, Lebwohl M. Clinical features of pyoderma gangrenosum and current diagnostic trends. J Am Acad of Dermatology. 2011;64(5):950-54(e2).

15. Wani I, Bhat IHG, Mir M, Mir M, Hassan N, Mustafa A. Pyoderma Gangrenosum of Abdominal Wall: A Case Report. Oman Med J. 2011;26(1):64-65. PMid:22043386 PMCid:3191625. http:// dx.doi.org/10.5001/omj.2011.18

16. Umezawa $Y$, Oyake $S$, Nagae T, Ishimaru S. A case of pyoderma gangrenosum on the stump of an amputated right leg. J. Dermatol. 2000;27(8):529-32. PMid:10989578.

17. Vasili E, Shkodrani E, Labinoti L, Xhaja A. A case of atypical pyoderma gangrenosum. J Dermatol Case Rep. 2010;4(1):18-21. PMid:21886741 PMCid:3157807. http://dx.doi.org/10.3315/ jdcr.2010.1044

18. Su WP, Davis MP, Weenig RH, Powell FC, Perry HO. Pyoderma gangrenosum: clinic pathologic correlation and proposed diagnostic criteria. Int J Dermatol. 2004;43:790-800. PMid:15533059. http://dx.doi.org/10.1111/j.1365-4632.2004.02128.x

19. Callen JP. Pyoderma gangrenosum. Lancet. 1998;351:581-5. http:// dx.doi.org/10.1016/S0140-6736(97)10187-8

20. Vignon-Pennamen MD, Wallach D. Neutrofilic disease: a review of extra-cutaneous manifestation. Eur J Dermatol. 1995;5:449-55.

21. Conrad C, Ralph M. Pyoderma Gangrenosum. Article Review. J Dtsch Dermatol Ges. 2005;3:334-42. PMid:16372799. http:// dx.doi.org/10.1111/j.1610-0387.2005.05022.x

22. Newman B, Cescon D, Domenchini A, Siminovitch KA. CD2BP1 and CARD 15 mutations are not associated with pyoderma gangrenosum in patients with inflammatory Bowel Disease. J Invest Dermatol. 2004;122:1054-5. PMid:15102098. http://dx.doi. org/10.1111/j.0022-202X.2004.22430.x

23. Sakiyama M, Kobayashi T, Nagata Y, Fujimoto N, Satoh T, Tajima S. Bullous pyoderma gangrenosum: $\mathrm{A}$ case report and review of the published work. J Dermatol. 2012;39(12):1010-1015.
24. Ferrándiz-Pulido C, García-Patos V. Pioderma gangrenoso Diagnóstico y tratamiento. Briones Piel. 2008;23(1):24-9. http:// dx.doi.org/10.1016/S0213-9251(08)70969-9

25. Zold E, Nagy A, Devenyi K, Zeher M, Barta Z. Successful use of adalimumab for treating fistulizing Crohn's disease with pyoderma gangrenosum: Two birds with one stone. World J Gastroenterol. 2009;15(18):2293-2295. PMid:19437575 PMCid:2682250. http://dx.doi.org/10.3748/wjg.15.2293

26. Hughes AP, Jackson JM, Callen JP. Clinical features and treatment of periostmal pyoderma gangrenosum. JAMA. 2000;284(12):1546-8. PMid:11000649. http://dx.doi.org/10.1001/jama.284.12.1546

27. Nukumizu LK, Silva CAA, Lotito APN, et al. Pioderma gangrenoso na infância e doenças sistêmicas associadas: relato de 5 casos. Rev Bras Reumatol. 2002;42:65-71.

28. Hoff NP, Gerber PA. Pyoderma gangrenosum associated with chronic polyarthritis. CMAJ. 2011;183(15):1746. PMid:21859868 PMCid:3193127. http://dx.doi.org/10.1503/cmaj.110679

29. Duke G, Samaraee A, Husain A, Meggitt S, Fasih T. Pyoderma Gangrenosum: A Rare Cause of Breast Ulceration. Ochsner J. 2012;12(2):155-158. PMid:22778682 PMCid:3387843.

30. Sheldon DG, Sawchuck LL, Kozarek RA, Thirlby RC. Twenty cases of periostomal pyoderma gangrenosum: diagnostic implications and management. Arch Surg. 2000;135(5):564-8. PMid:10807281. http://dx.doi.org/10.1001/archsurg.135.5.564

31. Fraga JCS, De Souza VL, Valverde RV, Gamonal A. Pioderma gangrenoso: apresentação atípica. An Bras Dermatol. 2006;81(5):S305-8

32. Weenig RH, Davis MD, Dahl PR, Su WP. Skin ulcers misdiagnosed as Pyoderma Gangrenosum. N Engl J Med. 2002;347:1412-8 PMid:12409543. http://dx.doi.org/10.1056/NEJMoa013383

33. Cliff S, Holden CA, Thomas PR, Marsden RA, Harland CC. Split skin grafts in the treatment of pyoderma gangrenosum. A report of four cases. Dermatol Surg. 1999;25(4):299-302. PMid:10417586. http://dx.doi.org/10.1046/j.1524-4725.1999.08193.x

34. Keltz $M$, Lebwhol M, Bishop S. Periostomal pyoderma gangrenosum.J Am Acad Dermatol. 1992;27:360-4. http://dx.doi. org/10.1016/0190-9622(92)70200-Y

35. Galun E, Flugelman MY, Rachmilewitz D. Pyoderma gangrenosum complicating ulcerative colitis: Successful treatment with methylprednisolone pulse therapy and dapsone. Am J Gastroenterol. 1986;81:988-9. PMid:3766502.

36. Friedman S, Marion JF, Scherl E, et al. Intravenous cyclosporine in refractory pyoderma gangre nosum complicating inflammatory bowel disease. Inflamm Bowel Dis. 2001;7(1):1-7. PMid:11233655 http://dx.doi.org/10.1097/00054725-200102000-00001

37. Miller J, Yentzer BA, Clark A, Jorizzo JL, Feldman SR. Pyoderma Gangrenosum: A review and update on new therapies. J Am Acad Dermatol. 2010;62(4):646-54. PMid:20227580. http://dx.doi. org/10.1016/j.jaad.2009.05.030

38. Federman $\mathrm{GL}$, Federman DG. Recalcitrant pyoderma gangrenosum treated with thalidomide. Mayo Clin Proc. 2000;75(8):842-4 PMid:10943240. http://dx.doi.org/10.4065/75.8.842

39. Stichweh DS, Punaro M, Pascual V. Dramatic improvement of pyoderma gangrenosum with infliximab in a patient with PAPA syndrome. Pediatr Dermatol. 2005;22:262-5. PMid:15916580. http://dx.doi.org/10.1111/j.1525-1470.2005.22320.x

40. Mir-Madjlessi S, Taylor JS, Farmer RG. Clinical course and evolution of erythema nodosum and pyoderma gangrenosum in chronic ulcerative colitis: A study of 42 patients. Am Gastroenterol. 1985;80:615-20. PMid:4025277. 
41. Binus AM, Qureshi AA, Li VW, Winterfield LS. Pyoderma gangrenosum: a retrospective review of patient characteristics, comorbidities, and therapy in 103 patients. Brit J Dermatol 2011;165:1244-1250. PMid:21824126. http://dx.doi. org/10.1111/j.1365-2133.2011.10565.x

42. Callen J, Jackson M. Pyoderma Gangrenosum: An Update. Rheum Dis Clin N Am. 2007;33:787-802. PMid:18037117. http://dx.doi. org/10.1016/j.rdc.2007.07.016

43. Kuhn C, Vente C, Dörner ], Ratayski H, Burchardi H. [Hypoderma gangrenosum and important differential diagnosis from woundinfection. Case report of a life threatening course]. Anaesthesist. 2000;49(9):829-33. PMid:11076272.
Correspondence

Clóvis Luíz Konopka

Av. Roraima, Prédio 22, Campus - Camobi, CEP 97105-900 - Santa Maria (RS), Brazil E-mail: cloviskonopka@gmail.com

Author information

CLK is an assistant professor of Vascular Surgery, Vascular Surgery Service, Hospital Universitário de Santa Maria, Universidade Federal de Santa Maria (UFSM).

GAP is a resident physician at the Dermatology Service of Hospital de Clínicas de Porto Alegre (HCPA)

MPO is a resident physician at the Anesthesiology Service of Hospital Universitário de Santa Maria, Universidade Federal de Santa Maria (UFSM)

$A K B$ is a monitor at the Angiology and Vascular Surgery Service of Hospital Universitário de Santa Maria, Universidade Federal de Santa Maria (UFSM)

MRB is a monitor at the Endocrinology Service of Hospital Universitário de Santa Maria, Universidade Federal de Santa Maria (UFSM).

DCD is a monitor at the Angiology and Vascular Surgery Service of Hospital Universitário de Santa Maria, Universidade Federal de Santa Maria (UFSM)

Author contributions Conception and design: CLK, GAP, MPO Analysis and interpretation: $A K B, M R B$ Data collection: CLK, BCF, AKB, MRB, MPO Writing the article: $C L K, B C F, M P O, G A P, A K B, M R B, D C D$ Critical revision of the article: $C L K, A K B, M R B, D C D$ Final approval of the article*: CLK, AKB,MRB, DCD, GAP, MPO Statistical analysis: N/A Overall responsibility: CLK

* All authors should have read and approved of the final version of the article submitted to I Vasc Bras. 